\title{
RNAs nonspecifically inhibit RNA polymerase II by preventing binding to the DNA template
}

\author{
DAVE A. PAI, ${ }^{1}$ CRAIG D. KAPLAN, ${ }^{2}$ HYE KYONG KWEON, ${ }^{1}$ KENJI MURAKAMI, ${ }^{3}$ PHILIP C. ANDREWS, ${ }^{1}$ \\ and DAVID R. ENGELKE ${ }^{1,4}$ \\ ${ }^{1}$ Department of Biological Chemistry, University of Michigan, Ann Arbor, Michigan 48109, USA \\ ${ }^{2}$ Department of Biochemistry and Biophysics, Texas A\&M University, College Station, Texas 77843, USA \\ ${ }^{3}$ Department of Structural Biology, Stanford University, Stanford, California 94305, USA
}

\begin{abstract}
Many RNAs are known to act as regulators of transcription in eukaryotes, including certain small RNAs that directly inhibit RNA polymerases both in prokaryotes and eukaryotes. We have examined the potential for a variety of RNAs to directly inhibit transcription by yeast RNA polymerase II (Pol II) and find that unstructured RNAs are potent inhibitors of purified yeast Pol II. Inhibition by RNA is achieved by blocking binding of the DNA template and requires binding of the RNA to Pol II prior to open complex formation. RNA is not able to displace a DNA template that is already stably bound to Pol II, nor can RNA inhibit elongating Pol II. Unstructured RNAs are more potent inhibitors than highly structured RNAs and can also block specific transcription initiation in the presence of basal transcription factors. Crosslinking studies with ultraviolet light show that unstructured RNA is most closely associated with the two large subunits of Pol II that comprise the template binding cleft, but the RNA has contacts in a basic residue channel behind the back wall of the active site. These results are distinct from previous observations of specific inhibition by small, structured RNAs in that they demonstrate a sensitivity of the holoenzyme to inhibition by unstructured RNA products that bind to a surface outside the DNA cleft. These results are discussed in terms of the need to prevent inhibition by RNAs, either though sequestration of nascent RNA or preemptive interaction of Pol II with the DNA template.
\end{abstract}

Keywords: Pol II; RNA inhibition; small RNA

\section{INTRODUCTION}

RNAs can be potent regulators of eukaryotic gene expression, both through modulation of RNA function and stability and through directed modification of chromatin (for reviews, see Storz et al. 2005; Hawkins and Morris 2008; Kurokawa et al. 2009; Morris 2011). Emerging data show that some small RNAs are able to directly inhibit RNA polymerases. The bacterial 6S RNA inhibits transcription by binding stably in the active site of RNA polymerase (Wassarman and Saecker 2006). In addition, there is evidence that certain structured RNAs in mammalian cells directly inhibit RNA polymerase II (Pol II). The RNA transcripts of B2 and Alu short interspersed elements (SINEs) inhibit transcription initiation by purified Pol II in vitro by binding directly to mammalian Pol II (Allen et al. 2004; Espinoza et al. 2004; Mariner et al. 2008; Yakovchuk et al. 2009; Ponicsan et al. 2013). These particular SINE transcripts appear to have evolved specific binding and inhibition properties to the structure of Pol II. SINEs

\footnotetext{
${ }^{4}$ Corresponding author

E-mail engelke@umich.edu

Article published online ahead of print. Article and publication date are at http://www.rnajournal.org/cgi/doi/10.1261/rna.040444.113.
}

can be actively transcribed in vitro by RNA polymerase III (Pol III), as expected since the various families of these high copy DNA elements in vertebrates are mostly derived by retrotransposition from transfer RNA (tRNA), 7SL RNA, or 5S ribosomal RNA (rRNA) genes (for reviews, see Okada 1991; Batzer and Deininger 2002; Weiner 2002; Price et al. 2004; Häsler and Strub 2006). Some SINE elements can also be transcribed by Pol II in vivo; and although SINEs are not normally found stably expressed at significant levels in vivo, they can be expressed under conditions of cell stress, viral infection, or in specific cell types (for review, see Lunyak and Atallah 2011). It is not clear whether the relative paucity of RNA from these high copy elements is entirely due to lack of transcription in vivo or whether rapid turnover of the RNA transcripts also takes place.

Direct inhibition of Pol II by RNAs has not been tested extensively in a yeast system, although an early report showed that tRNA can inhibit Pol II (Sawadogo 1981). The hypothesis

\footnotetext{
(C) 2014 Pai et al. This article is distributed exclusively by the RNA Society for the first 12 months after the full-issue publication date (see http://rnajournal. cshlp.org/site/misc/terms.xhtml). After 12 months, it is available under a Creative Commons License (Attribution-NonCommercial 4.0 International), as described at http://creativecommons.org/licenses/by-nc/4.0/.
} 
that tRNA transcripts might directly inhibit Pol II transcription is particularly interesting because Pol II transcription is antagonized in the immediate vicinity of tRNA genes (Kinsey and Sandmeyer 1991; Hull et al. 1994; Bolton and Boeke 2003). This local silencing of Pol II transcription by tRNA genes, termed tRNA gene-mediated (tgm) silencing, involves subnuclear clustering of the tRNA genes to the nucleolus (Wang et al. 2005) mediated by condensin (Haeusler et al. 2008) and modification of local chromatin structure (Good et al. 2013; Pratt-Hyatt et al. 2013). In addition, pretRNA transcripts appear necessary for silencing, but their contribution to the silencing mechanism remains uncharacterized (Pratt-Hyatt et al. 2013). Since tRNA and 5S rRNA genes are the only repetitive Pol III transcription units in yeast (there are no SINE elements in these small genomes), we initially set out to investigate the ability of these yeast transcripts to bind directly to purified Pol II from Saccharomyces cerevisiae and inhibit transcription.

Surprisingly, we show that not only tRNAs, but a variety of RNAs, inhibit Pol II transcription. In fact, unstructured RNAs are more effective inhibitors than highly structured tRNA or $5 \mathrm{~S}$ rRNA, suggesting a general inhibitory property rather than a mechanism evolved to recognize a specific RNA. We determine the nature of the Pol II-RNA interaction, distinguish it from the structured RNA inhibition shown in other studies, and discuss these results in terms of the likely need to sequester nascent transcripts from uncommitted RNA polymerase II.

\section{RESULTS}

\section{RNA prebound to Pol II inhibits transcription initiation}

We first asked whether preincubation of purified Pol II with RNAs could inhibit Pol II transcription in a nonspecific in vitro transcription assay that does not require basal transcription factors. To start, we assessed inhibitory activity of pre$\mathrm{tRNA}^{\mathrm{Tyr}}$. Pol II purified from S. cerevisiae was prebound to unlabeled pre-tRNA ${ }^{\mathrm{Tyr}}$, followed by addition of plasmid template, unlabeled nucleotide triphosphate (NTP) substrates, and $\alpha^{3}{ }^{32}$ P-UTP. Pol II initiates nonspecifically on the plasmid, creating a random size distribution of radioactive products that were quantitated (Fig. 1A, rightmost lane). With increasing amounts of pre-tRNA, Pol II transcripts are severely reduced (Fig. 1A, right to left), indicative of the
pre-tRNA inhibiting Pol II transcription (Fig. 1B, top left panel).

One hypothesis for the tgm silencing phenomenon is that the nascent transcripts from S. cerevisiae tRNA genes act locally as repressors of Pol II; therefore, our result that tRNA directly inhibits Pol II was intriguing. Yet it was not clear whether this inhibition would actually be tRNA-specific. Specificity would not be unprecedented since, for example, certain SINE transcripts have been shown to inhibit mammalian Pol II significantly better than others (Mariner et al. 2008). To determine whether Pol II inhibition by RNA was limited to tRNAs, we tested other RNAs with varied degrees of intrinsic structure for their ability to inhibit Pol II transcription in vitro, from tightly structured RNAs (5S rRNA) (Garrett and Olesen 1982) to RNAs predicted to be completely unstructured in solution (polyU RNA). We also tested a half-tRNA molecule, containing the first half of the pretRNA $^{\text {Tyr }}$ sequence but truncated just past the anticodon loop and lacking the tertiary structure of the full tRNA. Another RNA tested is a 250-nt region of the transcribed

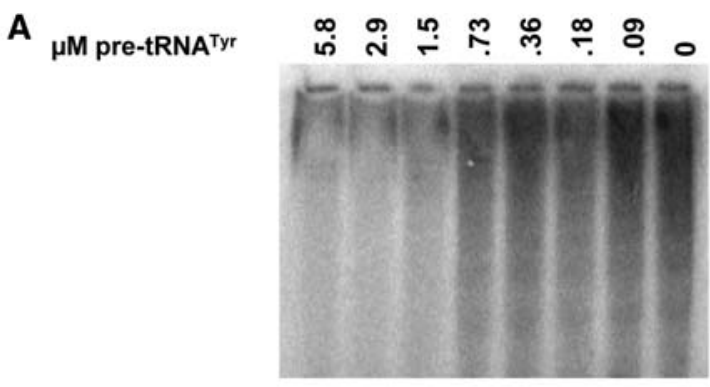

B

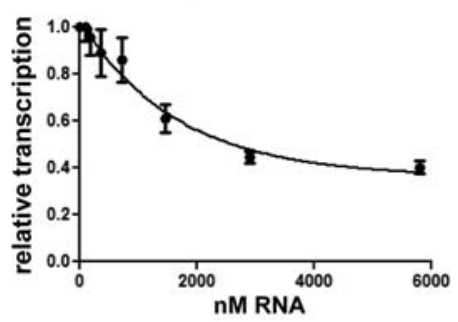

5S rRNA

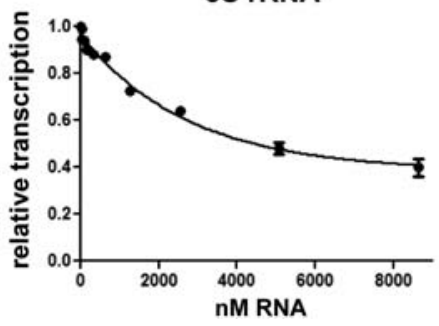

half tRNATyr

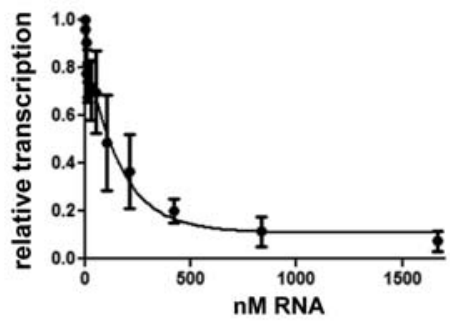

250 nt ORF RNA

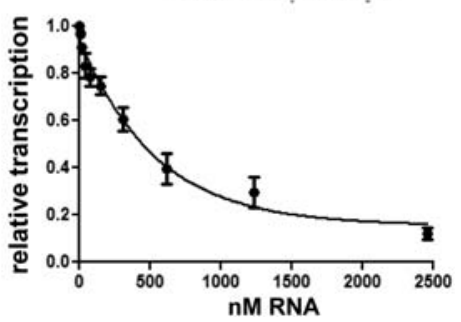

FIGURE 1. Preincubation of Pol II with RNAs inhibits transcript formation. (A) Inhibition of Pol II transcription by pre-tRNA ${ }^{\text {Tyr }}$. Indicated amounts of pre-tRNA ${ }^{\text {Tyr }}$ were incubated with a constant amount of Pol II $(30 \mathrm{nM})$ for $15 \mathrm{~min}$ at $30^{\circ} \mathrm{C}$. The Pol II-RNA complex was then incubated with plasmid DNA template and then added to NTPs. Reactions proceeded for $25 \mathrm{~min}$ and then were boiled in formamide and loaded onto a $10 \%$ denaturing gel. $(B)$ The reaction in $A$ was repeated in triplicate for four different RNAs. The total radioactive signal per lane was quantitated and plotted. 
PHO84 ORF of the yeast genome that is expected to have various local structures in aqueous solution, characteristic of mixed sequence RNAs, but not expected to be tightly structured overall. The transcription inhibition assay was repeated as for the pre-tRNA ${ }^{\text {Tyr }}$, in triplicate, and plotted (Fig. 1B). As with the pre-tRNA, the other three RNAs tested all inhibited transcription but to different degrees. Contrary to the hypothesis that tRNAs might have some specific ability to inhibit Pol II, the half-tRNA and the 250-nt ORF RNA inhibited better than the pre-tRNA and the 5S rRNA. For all RNAs, inhibition approaches a limit but falls short of completion at the concentrations tested, particularly for the more structured RNAs, suggesting that the intrinsic structure of those RNAs somehow hampers its ability to inhibit the enzyme. Thus, although a variety of RNAs can inhibit Pol II transcription, unstructured RNAs seem to be more potent inhibitors than structured ones. It is not entirely clear why inhibition is not complete for some RNAs. It is possible, for example, that there is more than one state of the Pol II in this highly purified fraction, and the ability to inhibit would be different between multiple states. It is also possible that the equilibrium in this assay that the off rate for Pol II bound to RNA inhibitors allows it to be captured by DNA at a low rate, but once Pol II is engaged in transcription on the DNA template, the off rate is much lower.

\section{Inhibition of Pol II by RNA occurs by preventing access to the DNA template}

To determine whether Pol II inhibition is due to a direct physical interaction between RNA and Pol II, the ability of purified Pol II to bind stably to RNA was demonstrated by electrophoretic mobility shift assays (EMSA). Incubation of the polymerase with RNA resulted in a complex that was stable to conditions of native electrophoresis (Fig. 2A, shown for the pre-tRNA ${ }^{\mathrm{Tyr}}$ ). We next asked whether RNA binding was interfering with template binding, transcription initiation, or transcript elongation. To do this, we performed a number of assays. For template binding, purified Pol II binding to purely double stranded DNA templates ("closed complexes") proved too unstable for reliable analysis by EMSA, so we directly tested the ability of RNA prebound to Pol II to interfere with the ability of Pol II to bind an

A

C "open complex," where the two DNA strands have been separated in a preinitiation bubble. RNA was prebound to Pol II, as in the transcription assays, then added to a radiolabeled 50 bp DNA template constructed to have a preexisting 15nt unpaired region. The prebound RNA-Pol II complex was incubated with this open DNA, and then complexes were separated on a native gel EMSA. Pol II binds the open DNA complex in the absence of RNA (Fig. 2B, second lane from right), although the Pol II-DNA complexes appear to be slightly unstable through the electrophoresis conditions, as evidenced by the slight smearing in the lane. As increasing amounts of RNA are preincubated with the Pol II (Fig. 2B, right to left), less of the DNA is bound to Pol II. Shifted signal was quantitated in triplicate and compared to total signal per
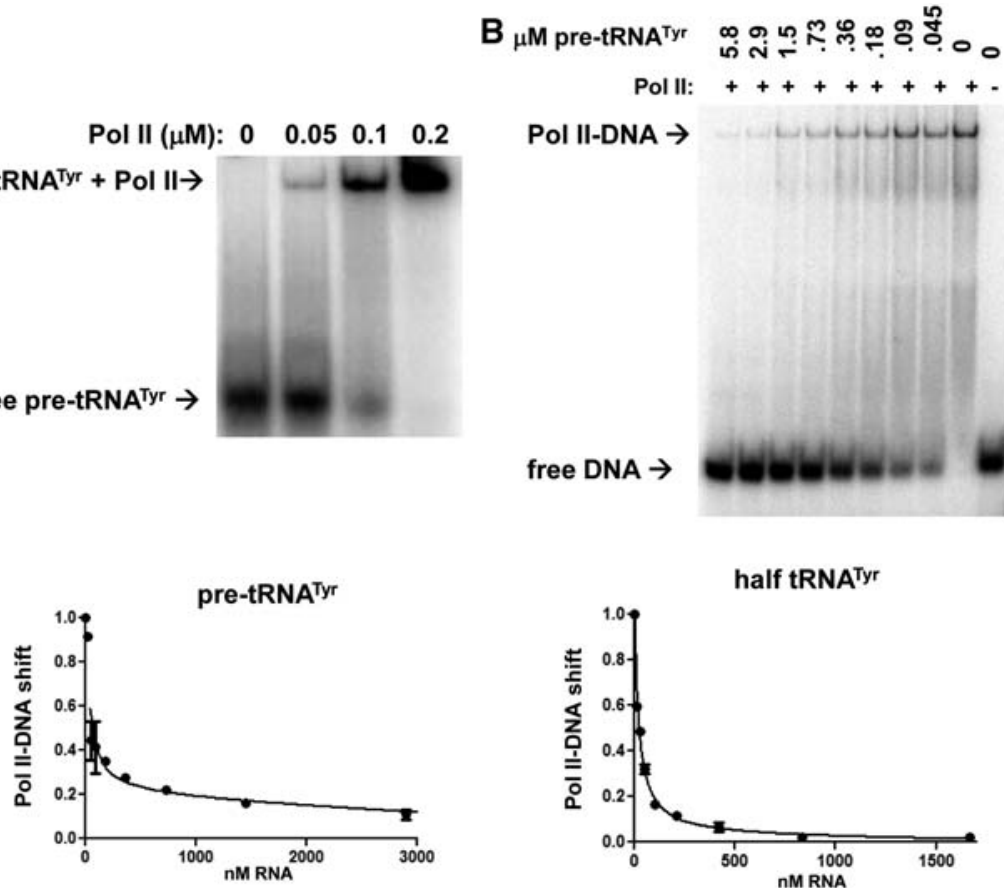

half tRNATyr
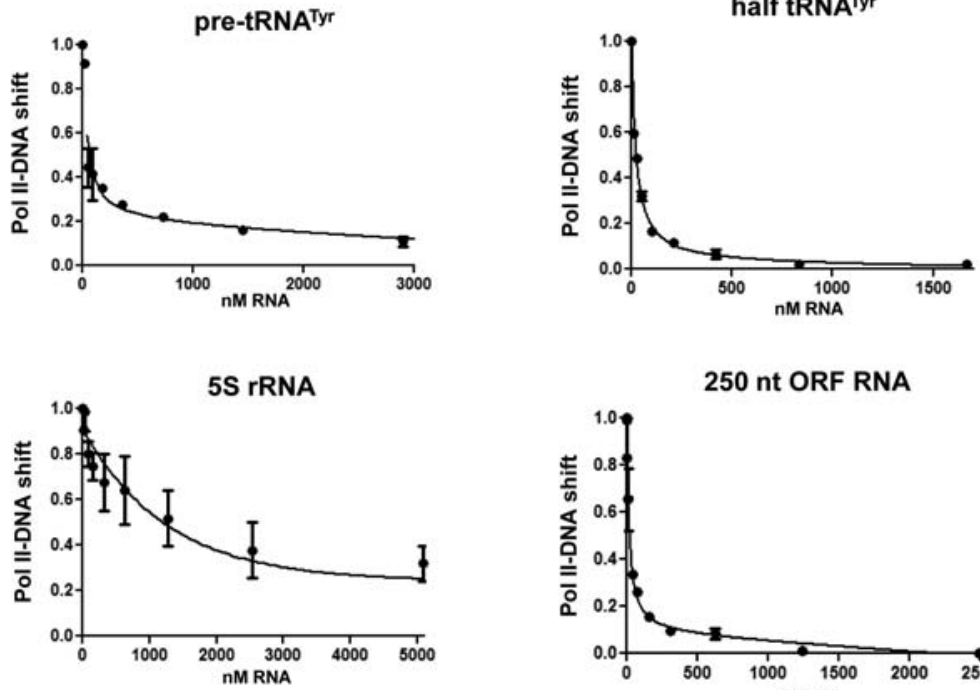

250 nt ORF RNA

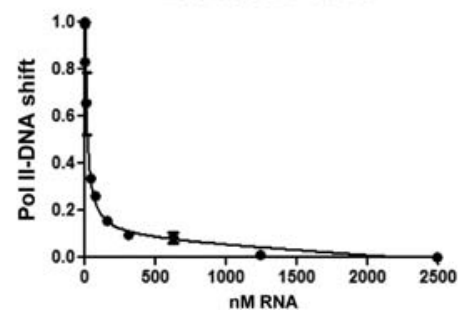

FIGURE 2. RNAs bind directly to Pol II and prevent the binding of Pol II to an open DNA complex. (A) Binding of Pol II to a pre-tRNA ${ }^{\text {Tyr }}$ transcript. A constant amount of $\alpha-{ }^{32} \mathrm{P}$ pre-tRNA ${ }^{\text {Tyr }}$ was incubated with titrated amounts of purified yeast Pol II and separated on a 5\% native polyacrylamide gel. (B) Inhibition by RNA of Pol II-DNA complex formation. Indicated amounts of tRNA $^{\text {Tyr }}$ were incubated with a constant amount of Pol II $(30 \mathrm{nM})$ for $15 \mathrm{~min}$ at $30^{\circ} \mathrm{C}$. These Pol II-RNA complexes were then incubated with the CKO432-CKO433 preformed open DNA complex for $15 \mathrm{~min}$ to a final volume of $10 \mu \mathrm{L}$. Complexes were separated on a 5\% native gel. The Pol II-DNA band separated from free DNA. $(C)$ The reaction in $B$ was repeated in triplicate for four different RNAs. Total radioactive signal per lane was quantitated and plotted. 
lane. This ratio of shifted DNA to total DNA was plotted for pre-tRNA, half-tRNA, 5S rRNA, and the 250-nt ORF RNA competitions (Fig. 2C). Once again, the unstructured RNAs prevent binding to the template more potently than the structured pre-tRNA and 5S rRNA. We note that the inhibition of open complex formation is more complete than the ability of the RNAs to inhibit randomly initiated transcription. Although the cause of this is not clear, it is possibly due to the fact that transcription complexes, once initiated, are more stable than the open complexes. Together, these results indicate that RNAs bind to Pol II and inhibit transcription by preventing the Pol II from accessing the DNA template.

This model predicts that preformation of a stable open complex between Pol II and the DNA template might preclude inhibition by RNA, as long as the RNA was not able to invade the complex to displace the DNA or to inhibit some other aspect of transcription (e.g., nucleotide acquisition). To test the first prediction, we first prebound the radiolabeled open DNA to Pol II and then added increasing levels of RNA. We used the pre-tRNA as an example of a structured RNA and the halftRNA as an unstructured RNA. Analysis was done via EMSA as in Figure 2. RNAs did not cause displacement of Pol II from the open DNA to any observable degree (Fig. 3A). We further tested the ability of RNAs to inhibit an elongation complex. Elongation inhibition assays were performed with the more unstructured RNAs (half tRNA and the 250-nt ORF RNA) to test optimal inhibitory conditions. In both cases, the RNAs were not able to significantly inhibit elongation by Pol II (Fig. 3B). Taken together, these results show that the RNA needs to prebind the polymerase in order to prevent binding of the polymerase to DNA.

We next assessed what length of the unstructured RNA was required to bind Pol II to achieve inhibition. Poly(U) RNA was used for this purpose to avoid issues of structure or sequence specificity as the length increases. Binding and inhibition assays were carried out as for the other RNAs, quantitated in triplicate, and plotted (Fig. 4A). The results using increasing poly(U) lengths demonstrate clearly that as the length of the RNA increases, binding of Pol II to the DNA template is inhibited more potently. Of note is a modest break point between 25 and $30 \mathrm{nt}$, suggesting RNA of this length or greater fits into the structure of Pol II in such a way as to provide better inhibition. Multiple contacts with the enzyme are likely being made by an RNA of this length, since the greater length is unlikely to lead to an intrinsic structure in $\operatorname{poly}(\mathrm{U})$. Repeating this experiment using single-stranded poly(dT) DNA of the same lengths showed similar length dependence although somewhat weaker
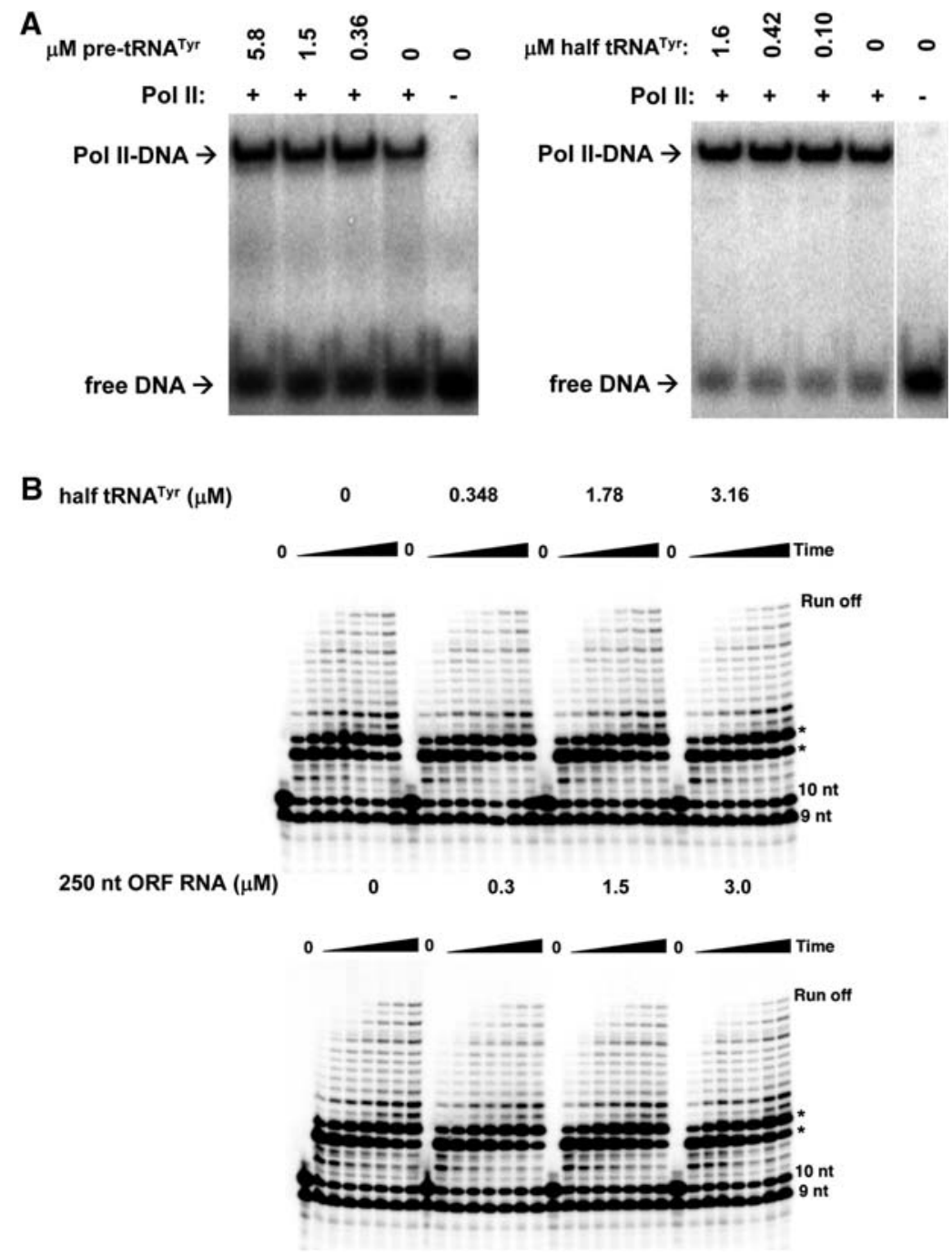

FIGURE 3. Preformed Pol II-DNA open complexes and preformed elongation scaffolds are not disrupted by RNAs. (A) Pol II was first incubated with the radiolabeled open DNA template for 15 min at $30^{\circ} \mathrm{C}$. Indicated amounts of RNA were then added to the Pol II-DNA complex and incubated for $15 \mathrm{~min}$ at $30^{\circ} \mathrm{C}$. Complexes were separated on a $5 \%$ native gel. (B) Template oligonucleotide DNA, partially mismatched nontemplate DNA, and a 9-nt RNA primer were annealed to form oligonucleotide elongation scaffolds. Purified Pol II was prebound to the scaffold, and active elongation complexes were advanced from 9 to $10 \mathrm{nt}$ by the addition of GTP $(1 \mu \mathrm{M})$. Complexes were then allowed to transcribe to the end of the template by the addition of all four NTPs $(10 \mu \mathrm{M}$ each) in the presence or absence of different concentrations of RNA (half tRNA or 250-nt ORF RNA, as shown). Transcription from scaffold templates with artificial transcription bubbles can often be inefficient, giving rise to transcription pausing and arrest, which can be seen here as RNA products that are larger than $10 \mathrm{nt}$ but shorter than the expected run-off product size. Sometimes dominant arrest points are observed, seen here at 14 and $15 \mathrm{nt}$ (denoted by asterisks). In any case, no inhibition of elongation is observed with addition of RNA. 


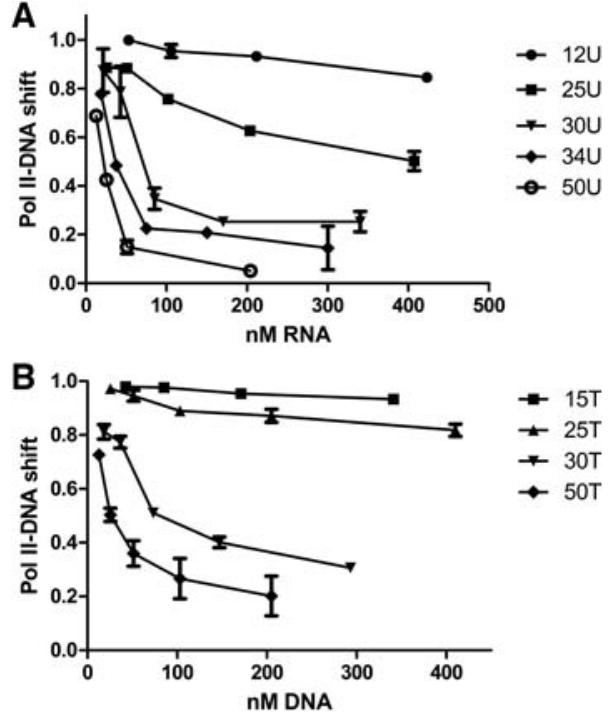

FIGURE 4. Inhibition of Pol II by RNA is not sequence-specific but is size-dependent. (A) Varying lengths of $\operatorname{poly}(\mathrm{U})$ RNA were incubated with Pol II for $15 \mathrm{~min}$ at $30^{\circ} \mathrm{C}$. The Pol II-RNA complex was then incubated with radiolabeled CKO432-CKO433 open DNA for $15 \mathrm{~min}$, and complexes were separated on a $5 \%$ native gel. Shifted bands were quantitated in triplicate relative to total signal for each RNA. (B) $A$ was repeated using varying lengths of poly $(\mathrm{dT})$ single-stranded DNA oligonucleotides.

inhibition (Fig. 4B). Thus, inhibition is not absolutely RNAspecific, though Pol II seems more likely to encounter single stranded RNA in vivo.

Having established that unstructured RNA binds strongly to Pol II, we investigated whether transcription inhibition would also occur in the presence of basal transcription factors. We tested two potential situations that could occur in vivo: RNA would encounter Pol II prior to assembly of the preinitiation complex (PIC); or the PIC would assemble prior to availability of any RNA. Testing inhibition by $\operatorname{poly}(\mathrm{U})_{50}$ of specific initiation off a promoter before and after addition of basal transcription factors showed potent inhibition of transcript formation (Fig. 5). This result demonstrates that this inhibitory mechanism is not limited to factor-independent initiation.

\section{Inhibitory RNAs bind near the active site of Pol II}

In the course of our experiments, we observed that Pol II was able to transfer radiolabel to the inhibitory RNAs, although the efficiency of such transfer was very low. Such activity is consistent with the RNA-dependent RNA polymerase (RdRP) activity observed for Pol II previously (Johnson and Chamberlin 1994; Lehmann et al. 2007). To test whether Pol II directly labels RNAs in this system, the structured and unstructured RNAs were incubated with Pol II and $\alpha-{ }^{32} \mathrm{P}-$ UTP in the absence of DNA template (Fig. 6A). All four RNAs were labeled, albeit inefficiently; and all four $\alpha{ }^{32} \mathrm{P}$-labeled NTPs could be added to the RNA substrate (Fig. 6B; data not shown) when used alone in the absence of other nucleo- tides. The assumption that reactions were catalyzed by the Pol II active site was confirmed by inhibition at low levels of the Pol II-specific inhibitor, $\alpha$-amanitin (Fig. 6C). This addition of nucleotides to RNA appears to be extremely inefficient, as only $\sim 0.1 \%$ of the RNA molecules become labeled. Endaddition therefore appears to be a property of only a small fraction of the bound RNA molecules and not a property of the majority of the inhibited complexes. Digestion with RNase $T_{1}$ confirms that the radiolabel is being added onto the $3^{\prime}$ end of the RNA (data not shown), consistent with previously observed RdRP activity of Pol II. The size heterogeneity of labeled RNA is likely due to heterogeneity at the $3^{\prime}$ end of the RNA substrate that results from T7 transcription. Assaying for increasing times ( $1 \mathrm{~min}$ to $2 \mathrm{~h}$ ) shows that the RNA does not processively increase in size, though the number of labeled molecules does increase with time (data not shown). We conclude that some of the RNAs bound by Pol II are positioned with their $3^{\prime}$ ends in the active site but are unable to distinguish inefficient catalysis from inappropriate positioning of most of the $3^{\prime}$ ends when stably bound.

\section{Inhibitory RNAs make contacts primarily with the two large subunits of Pol II}

We investigated where in the structure of Pol II the inhibitory RNAs were binding. Pol II was incubated with radiolabeled poly $(\mathrm{U})_{50} \mathrm{RNA}$, UV-crosslinked, denatured in formamide, and the crosslinked RNA-protein subunit complexes were isolated using denaturing gel electrophoresis (Fig. 7A). Each gel slice was treated with RNase A and trypsin and subject to LC-MS/MS analysis. The results indicate the vast majority of crosslinks were made with the two large subunits, Rpb1 and Rpb2 (Table 1). These two subunits form the bulk

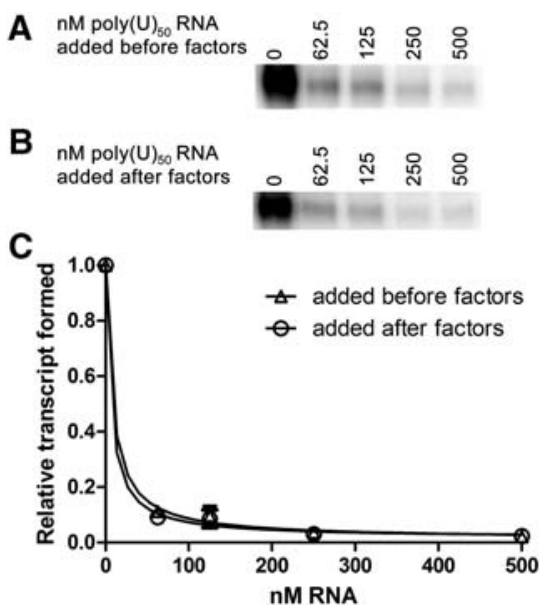

FIGURE 5. RNAs inhibit transcript formation when added either before or after basal transcription factors. (A) Varying concentrations of poly $(\mathrm{U})_{50}$ RNA were added prior to the addition of most of the general transcription factors. Transcription was allowed to proceed for $45 \mathrm{~min}$. (B) $A$ was repeated but with the addition of poly $(\mathrm{U})_{50}$ RNA after all of the general transcription factors. $(C) A$ and $B$ were performed in triplicate and quantitated. 
A

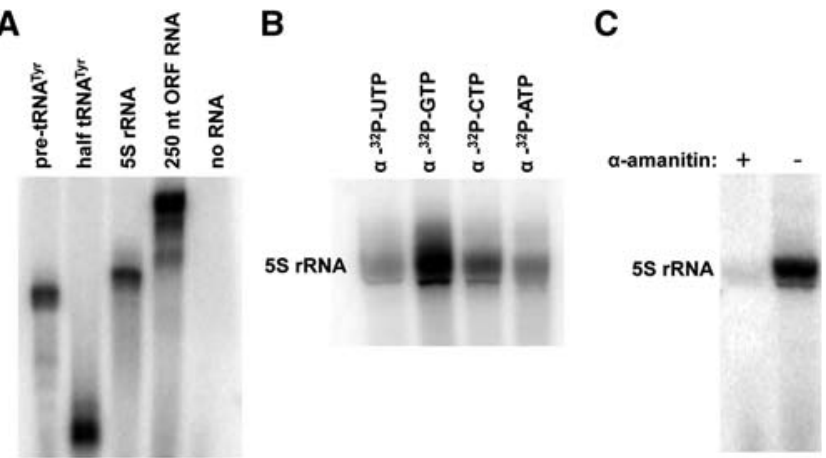

FIGURE 6. Template-independent labeling of RNAs by Pol II. (A) Pol II was incubated for $15 \mathrm{~min}$ at $30^{\circ} \mathrm{C}$ with $1 \mu \mathrm{g}$ each of pre-tRNA ${ }^{\text {Tyr }}$, half tRNA ${ }^{\text {Tyr }}, 5 S$ rRNA, and the 250-nt ORF RNA. $\alpha-{ }^{32} \mathrm{P}$-UTP was added in to Pol II-RNA complexes, with no DNA present in the reactions, and reactions proceeded for $30 \mathrm{~min}$ at $30^{\circ} \mathrm{C}$ and were run out on a $10 \%$ denaturing gel. All RNAs tested got radiolabel added in the absence of template DNA. (B) All four $\alpha_{-3}^{-3}$ P-labeled NTPs add label onto the RNAs (labeled 5S rRNA shown here). (C) Treatment with the Pol IIspecific inhibitor, $\alpha$-amanitin, prior to addition of RNA abolishes this labeling activity (5S rRNA shown here).

of the cleft for template binding (Fig. 7C), consistent with the RNA being in a position to compete with the DNA template.

We then determined the peptides that were in contact with the poly $(\mathrm{U})_{50} \mathrm{RNA}$. The above experiment was repeated, but the samples were subjected to trypsinization prior to gel isolation of the crosslinked species (Fig. 7B). The regions of shifted sample indicated in Figure $7 \mathrm{~B}$ were excised, treated with RNase A and trypsin as before, and again subjected to LC-MS/MS analysis. The peptides with the most reproducible association were from the parts of Rpb1 and Rpb2 located at the back wall of the Pol II structure (Fig. 7C; Table 2). The majority of the peptides formed an unexpected but interesting pattern in that the residues that were able to crosslink to the poly $(\mathrm{U})_{50}$ were not primarily in parts of the cleft occupied by DNA template. However, one Rpb1 peptide (positions 351-368) does present a small number of residues into the RNA-DNA hybrid-binding region, on a surface closer to the template DNA strand-binding surface than the product RNA-binding site surface. Furthermore, there is a pattern of associated peptides that wraps around the back of the Rpb1/Rpb2 structure, with one end at the opening of what has been suggested to be an alternative exit channel for the RNA, in a cleft formed first by a shoulder of Rpb2 adjacent to the RNA-DNA hybrid-binding region then proceeding to the region in the "back" of Pol II, where Rpb1 and Rpb2 interface with Rpb3, Rpb11, and Rpb12 (Cramer et al. 2001; Westover et al. 2004).

\section{DISCUSSION}

Transcription of tRNA genes in yeast antagonizes nearby Pol II transcription, but the mechanism of this silencing is not completely understood and appears distinct from other forms of transcriptional silencing in yeast (Hull et al. 1994; Perrod and Gasser 2003; Rusche et al. 2003; Wang et al. 2005). An active tRNA gene transcription complex is required, including condensin (Hull et al. 1994; Haeusler et al. 2008), and all tRNA genes genome-wide appear capable of forming such complexes (Kassavetis et al. 1990; Roberts et al. 2003; Moqtaderi and Struhl 2004; D'Ambrosio et al. 2008; Haeusler et al. 2008). Thus, the initial hypothesis for this study was that nascent pre-tRNAs might bind to Pol II in the immediate vicinity and inhibit transcription. The results of this study show that tRNAs can indeed inhibit transcription by Pol II, but inhibition by unstructured RNA is more robust. Thus, if the silencing involves direct interaction of the pre-tRNA with Pol II, it might need to be facilitated by additional components or a high local pre-tRNA concentration due to the spatially clustered tRNA genes (Bertrand et al. 1998; Thompson et al. 2003).

Previous work has shown at least two specific RNAs can bind tightly to yeast Pol II (Sawadogo 1981; Johnson and Chamberlin 1994). It has also been shown possible to select an RNA aptamer to Pol II (Thomas et al. 1997), and this aptamer in turn prevents DNA template binding to Pol II and can have nucleotides added onto its $3^{\prime}$ end (Lehmann et al. 2007). We show here, however, that there is no stringent sequence or structural requirement, since $\operatorname{poly}(\mathrm{U})$ homopolymers are able to inhibit at least as well as mixed sequence RNAs lacking poly(U) stretches. Further, results shown here for the more tightly structured RNAs (e.g., 5S rRNA) suggest that preexisting tight structure might interfere with inhibition. These results are not necessarily in conflict with earlier results showing that some small, structured RNAs might have evolved to specifically inhibit Pol II by fitting into the template binding site, whereas others are not good inhibitors (Allen et al. 2004; Espinoza et al. 2004; Mariner et al. 2008; Yakovchuk et al. 2009). In particular, it seems likely that inhibition of mammalian Pol II by mouse B2 and human Alu SINE RNAs might be caused by an entirely different type of RNA-polymerase interaction. The binding of B2 SINE RNA structures has been visualized both by crosslinking (Ponicsan et al. 2013) and crystallography (Kettenberger et al. 2006). In those cases, the RNA binds primarily inside the DNA cleft and active site region of mammalian Pol II, consistent with the RNA having evolved the ability to fit its tertiary structure stably into that site.

The highly structured RNAs used in our studies with yeast Pol II-tRNA and 5S rRNA—both have tight constraints on their structures due to functional requirements in translation, so it is not surprising that they are not especially aggressive competitors for DNA binding. What was surprising to us was how potent the relatively unstructured RNAs were at inhibiting DNA template binding without significantly affecting preformed preinitiation or elongation complexes. We originally assumed that this meant the RNA would physically occupy the DNA binding cleft, although this region is presumably more suited to binding at least partially 
A

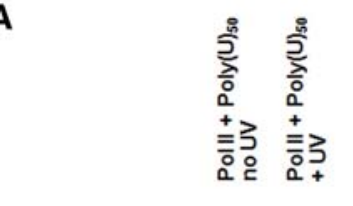

Polll-poly $(U)_{50} \rightarrow$

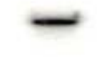

B

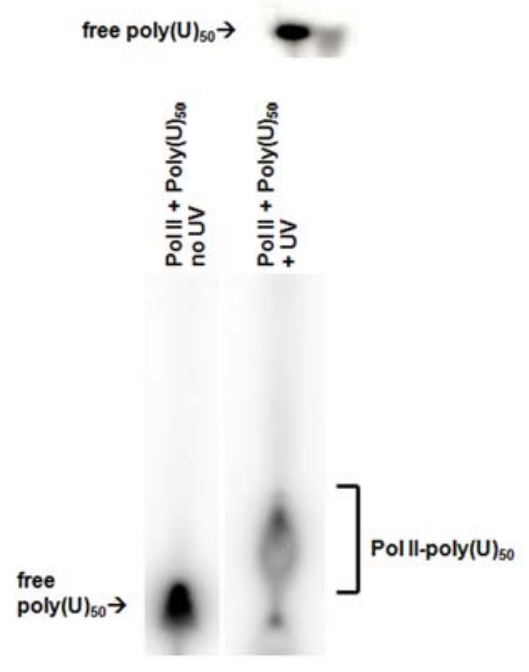

C
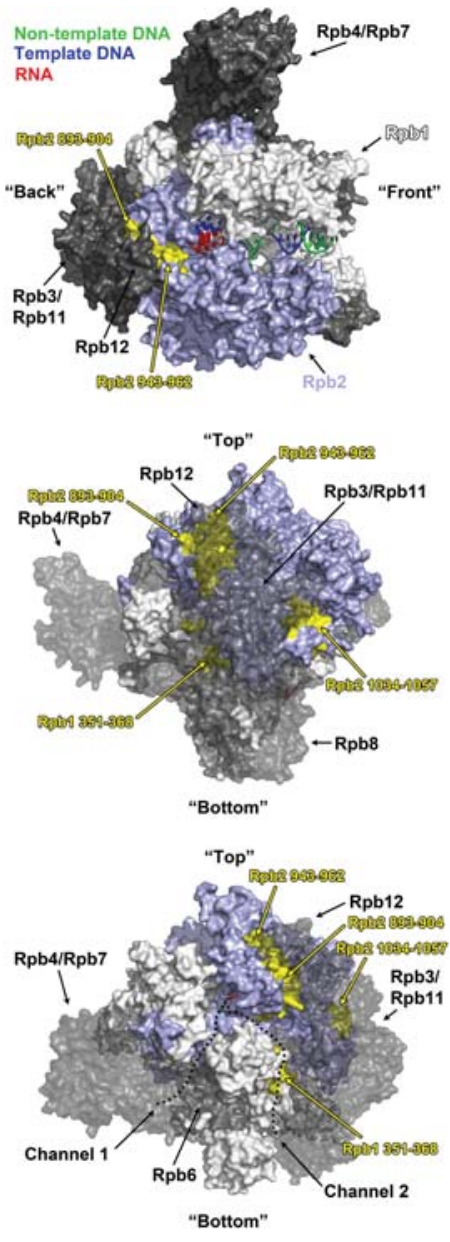

FIGURE 7. Binding of poly(U) RNA to Pol II subunits. (A) Purified Pol II was bound to poly $(\mathrm{U})_{50}$ RNA, either with or without UV crosslinking. Complexes were denatured with formamide and subjected to denaturing polyacrylamide gel electrophoresis to isolate subunits that become attached to the poly(U). The large shifted band in the presence of Pol II is usually a doublet, consistent with both Rpb1 and Rpb2 shifts. Binding reactions using Pol II and ${ }^{32} \mathrm{P}$-labeled poly(U) $+/$ - UV crossinking, shown, were run in parallel with identical unlabeled samples for excising shifted bands and analysis (Table 1). (B) Pol II was crosslinked to poly $(\mathrm{U})_{50}$ as in $A$, but before denaturation and electrophoretic separation, the complex was exhaustively digested with trypsin. Peptides reproducibly associated with the indicated shifted region were determined (Table 2). (C) Views of the Pol II holoenzyme (PDB 3po2, 51), with peptides from the shifted poly(U) band in $C$ shown in yellow. PDB entry 3 po2 contains 12 -subunit Pol II containing a nucleic acid scaffold comprising a template DNA strand (blue), a partially visible nontemplate strand (green), and a product RNA (red), illustrating RNA in an RNA-DNA hybrid with template DNA with a number of bases present in a long backtrack (not visible in the views shown). (Top) 12-subunit Pol II holoenzyme, illustrating the "crab claw" shape of Pol II with the large subunits (Rpb1 in white, Rpb2 in light blue) comprising one claw each, with template DNA and RNA-DNA hybrid bound between them. Other subunits are in gray, with Rpb4/Rpb7 forming a stalk to one side of Pol II. (Middle) "Back view" of Pol II from behind, with Rpb3-Rpb12 rendered as partially transparent. (Bottom) "Back view" as above but tilted toward Rpb4/Rpb7 to illustrate positions of possible RNA channels 1 and 2. Channel 1 is experimentally supported as the RNA exit channel, whereas Channel 2 is electrostatically favorable for RNA interaction.

double-stranded nucleic acids. However, the length of RNA required for full effect suggested that RNA might be making multiple contacts with Pol II. To examine this interaction in more detail, we deliberately chose poly(U) to circumvent the possibility of any strong secondary or tertiary structure in the RNA, other than what might occur through binding to the protein. Although the $\operatorname{poly}(\mathrm{U})_{50}$ does crosslink to the two large subunits that surround DNA cleft and active site (Rpb1/Rpb2), the peptides that are actually found attached to the RNA after trypsin digestion map to an unexpected surface. Most of the peptides form a line on the back side of the back wall of the template cleft, a region that interfaces with Rpb3, Rpb11, and Rpb12, but has not previously been associated with nucleic acid binding. This line appears to begin on the outer periphery of Rpb2, at the edge of what had previously been speculated to be an alternative exit channel for RNA transcripts based on proximity to the RNA-DNA hybrid-binding region and electrostatic favorability for nucleic acid interactions (Cramer et al. 2001; Westover et al. 2004). Although the optimum length for a poly $(U)$ inhibitor suggests there could also be parts of the RNA chain occupying portions of this channel or the DNA cleft, it does not appear that there are bases in close enough contact with appropriate amino acids for UV-induced crosslinks. There could, for example, be only basic residue interactions with the phosphate backbone, consistent with the apparent lack of sequence specificity in the binding. The ability of the enzyme to add additional nucleotides to some $3^{\prime}$ ends suggests that at least some fraction of the bound RNAs have their $3^{\prime}$ termini in the active site. Further structural determination of the Pol II complex with a tightly bound linear RNA might resolve this issue if the bound states are sufficiently uniform.

This mode of RNA binding by Pol II might be entirely distinct from those of SINE RNAs, both structurally and functionally. Although selected SINE RNAs have been postulated to be specifically evolved inhibitors of Pol II, these observations suggest any RNA has the potential for product inhibition, if allowed unfettered access to an unengaged RNA polymerase II. One way the RNA polymerase might evade this inhibition is to be chaperoned by transcription factors, including Mediator (Cai et al. 2010; Bernecky et al. 2011; Soutourina et al. 2011; He et al. 2013), or some other bound proteins that prevent access to this RNA binding surface or actively displace the RNA once bound. Initiation factors might also privilege the template 
TABLE 1. Subunits of Pol II identified from LC-MS/MS analysis of excised gel slice in Figure $7 \mathrm{~A}$

\begin{tabular}{lccccc}
\hline Subunit & $\begin{array}{c}\text { Unweighted } \\
\text { spectral counts: } \\
\text { negative control } \\
\text { name }\end{array}$ & $\begin{array}{c}\text { Unweighted } \\
\text { spectral counts: } \\
\text { Pol II + Poly }(\mathrm{U})_{50}\end{array}$ & $\begin{array}{c}\text { Number of } \\
\text { unique } \\
\text { peptides }\end{array}$ & $\begin{array}{c}\text { Total } \\
\text { counts } \\
(\%)\end{array}$ & $\begin{array}{c}\text { Sequence } \\
\text { coverage } \\
(\%)\end{array}$ \\
\hline Rpb1 & 0 & 3601 & 116 & 47.9 & 65.40 \\
Rpb2 & 0 & 3248 & 107 & 43.2 & 69.30 \\
Rpb5 & 0 & 189 & 16 & 2.5 & 72.60 \\
Rpb7 & 0 & 103 & 10 & 1.4 & 74.90 \\
Rpb9 & 0 & 98 & 6 & 1.3 & 53.30 \\
Rpb3 & 0 & 93 & 11 & 1.2 & 44.00 \\
Rpb10 & 0 & 60 & 5 & 0.8 & 62.90 \\
Rpb11 & 0 & 39 & 10 & 0.5 & 61.70 \\
Rpb12 & 0 & 34 & 4 & 0.5 & 52.90 \\
Rpb8 & 0 & 14 & 5 & 0.2 & 36.30 \\
Rpb4 & 0 & 12 & 3 & 0.2 & 15.40 \\
\hline
\end{tabular}

No Pol II subunits were identified in the parallel sample containing no RNA, as expected, consistent with proteins being unable to migrate into a urea gel unless crosslinked to RNA. The great majority of spectral counts were identified in the two large subunits of Pol II, with low levels of peptides from other subunits.

DNA for insertion into the Pol II active site and displace competing nucleic acids; although in this in vitro assay, the basal transcription factors that allow minimum promoter recognition did not protect from RNA-mediated inhibition.

Another factor is that naked RNA is simply not very accessible in the nucleus, making it difficult to assess whether uncommitted Pol II in nuclear nanoenvironments is exposed to the mid-nanomolar levels at which we see inhibition by unstructured RNAs. Nuclear processes are largely arranged in a way that does not allow substantial concentrations of unchaperoned RNAs to accumulate in the vicinity of Pol II transcription. Pre-mRNAs are assembled into ribonucleoprotein complexes and processed cotranscriptionally. In addition, the massive synthesis of ribosomal RNAs is resolved by not only assembling and processing them cotranscriptionally but by segregating these factories into specific subnuclear areas, i.e., nucleoli. The timing and spatial organization of assembly of the small RNAs into RNPs is somewhat less understood but also spatially segregated. All acquire some number of protein partners early in their biosynthesis. In yeast, the most abundant small RNAs made by Pol III-pre-tRNA and 5S rRNA - not only bind La and Lsm proteins (Maraia and Intine 2002; Wilusz and Wilusz 2005; Phizicky and Hopper 2010), but also have their genes clustered at the nucleolus (Bertrand et al. 1998; Thompson et al. 2003; Wang et al. 2005), thus sequestering them away from most of the centers of Pol II transcription.

This study demonstrates that nonspecific RNAs can bind to Pol II and prevent binding of Pol II to a DNA template.

TABLE 2. Peptides identified from LC-MS/MS analysis of excised gel fragment in Figure 7B

\begin{tabular}{|c|c|c|c|c|c|c|c|}
\hline Subunit & $\begin{array}{c}\text { Sequence } \\
\text { coverage } \\
(\%)\end{array}$ & $\begin{array}{l}\text { Total } \\
\text { spectra } \\
(\%)\end{array}$ & $\begin{array}{c}\text { Number } \\
\text { of total } \\
\text { spectra }\end{array}$ & $\begin{array}{c}\text { Number } \\
\text { of unique } \\
\text { spectra }\end{array}$ & $\begin{array}{l}\text { Number } \\
\text { of unique } \\
\text { peptides }\end{array}$ & $\begin{array}{l}\text { Number } \\
\text { of spectra }\end{array}$ & Peptide sequence \\
\hline \multirow[t]{9}{*}{ Rpb1 } & 7.21 & 0.36 & 174 & 10 & 9 & 113 & 351-TVISGDPNLELDQVGVPK-368 \\
\hline & & & & & & 32 & 373-TLTYPEVVTPYNIDR-387 \\
\hline & & & & & & 17 & 1459-ITEIEDGQDGGVTPYSNESGLVNADLDVK-1487 \\
\hline & & & & & & 5 & 190-ATGDADEPELR-200 \\
\hline & & & & & & 2 & 678-EITETIAEAK-687 \\
\hline & & & & & & 2 & 925-LQVLLDEEYK-934 \\
\hline & & & & & & 1 & 712-ESFEDNVVR-720 \\
\hline & & & & & & 1 & 50-IGGLNDPR-57 \\
\hline & & & & & & 1 & 881-qSLDTIGGSDAAFEK-895 \\
\hline \multirow[t]{7}{*}{ Rpb2 } & 8.66 & 0.20 & 100 & 9 & 7 & 26 & 943-STENGIVDQVLVTTNQDGLK-962 \\
\hline & & & & & & 25 & 893-LDDDGLIAPGVR-904 \\
\hline & & & & & & 18 & 1034-VAALSGNEGDASPFTDITVEGISK-1057 \\
\hline & & & & & & 11 & 905-VSGEDVIIGK-914 \\
\hline & & & & & & 10 & 915-TTPISPDEEELGQR-928 \\
\hline & & & & & & 7 & 136-TYEAIDVPGR-145 \\
\hline & & & & & & 3 & 149-YELIAEESEDDSESGK-164 \\
\hline
\end{tabular}

As in Table 1, no peptides were identified in the parallel sample containing no RNA, so only peptides crosslinked to RNA would be identified here. Filtering criteria were $95 \%$ peptide identification probability with a false discovery rate of less than 0.01 . This experiment was done in triplicate, with the highest confidence data set (based on peptide recovery and lack of contaminating peptides) listed below. The peptides identified in our model (Fig. 7C) are those that showed the highest hits in this table and were also reproducible in at least one of the other two replicates. The second-highest hit in Rpb1 (373-387) was not reproducible in the other two replicates and so was not included in our model, but because it is adjacent to the most prevalent peptide (351-368), we suspect it may have come down as a result of initial incomplete trypsinization. 
Although both structured and unstructured RNAs can inhibit Pol II transcription, the flexible RNAs used here appear to bind to a different surface than envisioned for small, highly structured RNAs and have inhibition properties that are at least somewhat different. These observations suggest cellular mechanisms to segregate the highly transcribed RNAs away from uncommitted Pol II are likely necessary. In light of the data that many RNAs have been shown to regulate eukaryotic gene expression by diverse mechanisms, our results are consistent with the potential for nuclear RNAs to be direct repressors of transcription.

\section{MATERIALS AND METHODS}

\section{RNA preparation}

Yeast precursor tRNA ${ }^{\text {Tyr }}$ (pre-tRNA ${ }^{\text {Tyr }}$ ) (Goodman et al. 1977), a half-pre-tRNA ${ }^{\mathrm{Tyr}}$ generated by inserting a poly(T) terminator in the coding sequence of pre-tRNA ${ }^{\mathrm{Tyr}}$ just past the anticodon loop (5'-CUCUCGGUAGCCAAGUUGGUUUAAGGCGCAAGACUGU AAUUUUUUU- $3^{\prime}$ ), yeast 5 S ribosomal RNA (rRNA), and a 250-nt mixed-sequence RNA from the PHO84 gene (Chromosome XIII, coordinates 24237 to 25486 ) were transcribed from linear DNA templates using T7 RNA polymerase (Milligan and Uhlenbeck 1989). Radiolabeled pre-tRNA ${ }^{\mathrm{Tyr}}$ was transcribed using T7 RNA polymerase in reactions containing $1 \mu \mathrm{M} \alpha-{ }^{32} \mathrm{P}-\mathrm{UTP}$ (Milligan and Uhlenbeck 1989). The RNAs were then purified by passive elution from denaturing polyacrylamide gels. $\operatorname{Poly}(\mathrm{U})_{50}$ RNA was purchased from Integrated DNA Technology. The smaller sizes of poly(U) RNA were generated by alkaline hydrolysis and subsequent purification by passive elution from denaturing polyacrylamide gels (Marvin et al. 2011).

\section{Pol II transcription assays}

In vitro-transcribed RNAs to be used in Pol II transcription inhibitions were serially diluted in water. Three hundred femtomoles purified 12-subunit Pol II (Elmlund et al. 2010) were added to the indicated amount of RNA in $5 \mu \mathrm{L}$ transcription buffer $(20 \mathrm{mM}$ Tris $\mathrm{pH}$ 8.0, $40 \mathrm{mM} \mathrm{KCl}, 5 \mathrm{mM} \mathrm{MgCl}_{2}$, and $1 \mathrm{mMDTT}$ ). Pol II-RNA complexes were allowed to bind for $15 \mathrm{~min}$ at $30^{\circ} \mathrm{C}$. Four hundred nanograms of plasmid DNA (Hull et al. 1994) were added to the reaction, incubated briefly $(2-3 \mathrm{~min})$ at $30^{\circ} \mathrm{C}$, before nucleotide triphosphates (NTPs) were added (ATP, CTP, and GTP at $500 \mu \mathrm{M}$ final; UTP at $9 \mu \mathrm{M}$ final; and $\alpha-{ }^{32} \mathrm{P}-\mathrm{UTP}$ [PerkinElmer] at $1 \mu \mathrm{M}$ final) to a final reaction volume of $10 \mu \mathrm{L}$. Transcription by Pol II from nonspecific initiation sites was allowed to proceed for $25 \mathrm{~min}$ at $30^{\circ} \mathrm{C}$. Samples were boiled in formamide and analyzed on a 10\% denaturing gel. The gel was dried and exposed onto a Typhoon Trio+ cassette (Molecular Dynamics), and total radioactive signal per lane was quantitated with Image $J$ (National Institutes of Health) and plotted with GraphPad Prism.

\section{Electrophoretic mobility shift assays}

For the Pol II-RNA binding assay, amounts of Pol II as shown were added to $4 \mathrm{nM}$ radiolabeled pre-tRNA ${ }^{\mathrm{Tyr}}$ in EMSA buffer $(20 \mathrm{mM}$ Tris $\mathrm{pH} 8.0,10 \%$ glycerol, $1 \mathrm{mM}$ DTT, $5 \mathrm{mM} \mathrm{MgCl}_{2}, 40 \mathrm{mM}$ $\mathrm{KCl}$, and $100 \mu \mathrm{g} / \mathrm{mL}$ bovine serum albumin) to a final reaction vol- ume of $10 \mu \mathrm{L}$. Pol II-tRNA complexes were allowed to bind for 15 min at $30^{\circ} \mathrm{C}$ and then separated on a $5 \%$ nondenaturing polyacrylamide gel (40:1 acrylamide:bis, supplemented with 5\% glycerol and $5 \mathrm{mM} \mathrm{MgCl}_{2}$, in Tris-Borate buffer supplemented with $5 \mathrm{mM}$ $\mathrm{MgCl}_{2}$ ). The gel was dried, exposed, and scanned as above.

For Pol II-DNA binding inhibition assays, radiolabeled DNA was generated by end-labeling DNA oligonucleotide CKO433 (5'-gggttggcttttcgccGTGTCCCTCTCGATGgctgtaagtaaggctatgg-3') with $\gamma^{-32}$ P-ATP (PerkinElmer). The end-labeled oligonucleotide was then annealed to DNA oligonucleotide CKO432 (5'-ccatag ccttacttacagcGTAGCTCTCCCTGTGggcgaaaagccaaccc- $3^{\prime}$ ) by slow cooling from $65^{\circ} \mathrm{C}$ to $25^{\circ} \mathrm{C}$ to generate a "bubbled" DNA fragment (the sequences in capital letters denote the mismatched, "bubbled" region) used to create open preinitiation complexes with Pol II. After annealing the two strands, the double-stranded DNA was purified away from free oligonucleotide by passive elution out of a $6 \%$ nondenaturing polyacrylamide gel and precipitated. For inhibition assays, Pol II ( $30 \mathrm{nM}$ ) was preincubated with RNA for $15 \mathrm{~min}$ at $30^{\circ} \mathrm{C}$ in $5 \mu \mathrm{L}$ EMSA buffer. The labeled CKO433-CKO432 open DNA complex was then added to Pol II-RNA complexes in a final volume of $10 \mu \mathrm{L}$ EMSA buffer. Complexes were allowed to bind for $15 \mathrm{~min}$ at $30^{\circ} \mathrm{C}$. Formation of Pol II-DNA complexes was analyzed by EMSA as above. Where prebinding of Pol II-DNA was tested, Pol II was first added to end-labeled DNA, allowed to bind for 15 $\min$ at $30^{\circ} \mathrm{C}$, and then RNA was added for $15 \mathrm{~min}$. Reactions proceeded otherwise in the same fashion. All controls for inhibitor titrations were contained within individual experiments, as variability in binding assays (e.g., Fig. 3, panel A) was observed on freeze/thaw cycles of purified enzyme fractions.

\section{Elongation inhibition assays}

Transcription on annealed oligonucleotide elongation scaffolds was performed basically as described in Kaplan et al. (2008) with the following modifications. Elongation scaffolds were formed using partially mismatched DNA oligonucleotides, allowing single-step annealing of template, nontemplate, and $5^{\prime}$-radiolabeled RNA primer. Two micromoles of template DNA (CKO433), nontemplate DNA (CKO432), and 9-nt RNA primer (RNA9) in $10 \mu \mathrm{L}$ in vitro transcription buffer (IVT buffer) $\left(5 \mathrm{mM} \mathrm{MgCl}_{2}, 20 \mathrm{mM}\right.$ Tris- $\mathrm{HCl}$, $\mathrm{pH}$ 8.0, $40 \mathrm{mM} \mathrm{KCl}, 2 \mathrm{mM}$ DTT) were annealed by slow cooling from $65^{\circ} \mathrm{C}$ to $25^{\circ} \mathrm{C}$ to form elongation scaffolds. Five microliters of scaffold were mixed with $5 \mu \mathrm{L}$ purified Pol II $(\sim 2 \mu \mathrm{M})$ (Kaplan et al. 2008) and incubated for $5 \mathrm{~min}$ at room temperature. Complexes were diluted 20-fold in IVT buffer and aliquoted for addition of NTPs with or without inhibitory RNAs. Productive scaffolds were advanced $1 \mathrm{nt}$ by the addition of $10 \mu \mathrm{M}$ GTP (in IVT buffer) to a final concentration of $1 \mu \mathrm{M}$ for $5 \mathrm{~min}$ at room temperature. Run-off transcription was initiated by the addition of $10 \mu \mathrm{M}$ of all four NTPs with or without differing concentrations of inhibitory RNA species. Aliquots of each reaction at time points from $10 \mathrm{sec}$ to $5 \mathrm{~min}$ were quenched and analyzed by polyacrylamide gel electrophoresis as previously described (Kaplan et al. 2008).

\section{Inhibition of specific initiation with general transcription factors}

General transcription factors were prepared, and specific transcription initiation assayed as described (Murakami et al. 2013). For 
inhibition before addition of most general transcription factors, varied concentration of $\operatorname{poly}(\mathrm{U})_{50}$ RNA were incubated with $1.5 \mathrm{pmol}$ of Pol II-TFIIF for $3 \mathrm{~h}$ on ice, then combined with 1.5 pmol of HIS4 promoter DNA (-96/+112), 5.3 pmol of TFIIA, $6.1 \mathrm{pmol}$ of TFIIB, $1.5 \mathrm{pmol}$ of TBP, $4.5 \mathrm{pmol}$ of TFIIE, $2.25 \mathrm{pmol}$ of TFIIHdeltaTFIIK, and $3.0 \mathrm{pmol}$ of TFIIK in $4.5 \mu \mathrm{L}$ of buffer $(20 \mathrm{mM}$ HEPES pH7.6, $300 \mathrm{mM}$ potassium acetate, $5 \mathrm{mM}$ DTT, $2 \mathrm{mM}$ magnesium acetate, $5 \%$ glycerol). To assemble the PIC, the protein mixture was combined with $5.5 \mu \mathrm{L}$ of buffer (50 mM HEPES pH7.6, $20 \mathrm{mM}$ potassium acetate, $5 \mathrm{mM}$ magnesium sulfate, $5 \mathrm{mM}$ DTT) and incubated for $1 \mathrm{~h}$ on ice. Transcription was initiated by adding $10 \mu \mathrm{L}$ of $2 \mathrm{x}$ NTPs (50 mM HEPES pH7.6, $20 \mathrm{mM}$ potassium acetate, $5 \mathrm{mM}$ magnesium sulfate, $5 \mathrm{mM}$ DTT, $1.6 \mathrm{mM}$ ATP, $1.6 \mathrm{mM}$ GTP, $1.6 \mathrm{mM}$ CTP, $40 \mu \mathrm{m}$ UTP, $0.083 \mu \mathrm{M} \alpha-{ }^{32} \mathrm{P}-\mathrm{UTP}, 10 \mathrm{mM}$ magnesium acetate, and 5 units of RNaseOUT [Life Technologies]). The reaction was stopped after $45 \mathrm{~min}$ and defined-length run-off transcripts from the promoter were analyzed as described (Murakami et al. 2013). To test inhibition after addition of most factors, the PIC was assembled as above but before the addition of RNA inhibitor; Poly $(\mathrm{U})_{50}$ RNA was then added after PIC assembly and incubated for $1 \mathrm{~h}$ on ice before adding $2 \times$ NTP buffer.

\section{Labeling of added RNAs by Pol II}

Five-tenths microgram Pol II was preincubated with $1 \mu \mathrm{g}$ of desired RNA for $15 \mathrm{~min}$ at $30^{\circ} \mathrm{C}$ in $5 \mu \mathrm{L}$ transcription buffer. $\alpha-{ }^{32} \mathrm{P}$-UTP was added in to $1 \mu \mathrm{M}$ in a final volume of $10 \mu \mathrm{L}$ of transcription buffer, and the reaction was allowed to proceed for $30 \mathrm{~min}$ at $30^{\circ} \mathrm{C}$. Reactions were then run out on a $10 \%$ denaturing gel. The gel was dried, exposed, and scanned as above. RNA-labeling efficiency was estimated by measuring $a^{-}{ }^{32} \mathrm{P}$ incorporation into otherwise unlabeled RNA. For treatment with $\alpha$-amanitin, the inhibitor was added to a $50 \mathrm{ng} / \mu \mathrm{L}$ final concentration and allowed to bind for $5 \mathrm{~min}$ prior to adding RNA.

\section{Pol II-RNA crosslinking for mass spectrometry}

For identification of protein subunits, $2 \mu \mathrm{g}$ of Pol II were added to $100 \mathrm{ng}$ of poly $(\mathrm{U})_{50}$ RNA in $10 \mu \mathrm{L}$ Binding Buffer $(20 \mathrm{mM}$ Tris $\mathrm{pH}$ 8, $40 \mathrm{mM} \mathrm{NaCl}, 5 \mathrm{mM} \mathrm{MgCl}_{2}, 1 \mathrm{mM} \mathrm{DTT}, 5 \%$ glycerol). Pol II-RNA complexes were allowed to bind for $15 \mathrm{~min}$ at $30^{\circ} \mathrm{C}$. The tubes containing the samples were placed flat inside a CL-1000 Ultraviolet Crosslinker (UVP) and crosslinked at $240,000 \mu \mathrm{J} / \mathrm{cm}^{2}$ (2 min). Tubes were flipped over and crosslinked again. Samples were denatured at $95^{\circ} \mathrm{C}$ in formamide and separated on a $6 \%$ denaturing gel. The location of the Pol II-bound RNA was determined by running a parallel sample with radiolabeled RNA in a neighboring lane. The gel slice containing Pol II-bound RNA was excised and placed in water containing $10 \mathrm{ng}$ of RNase A and incubated for 2 $\mathrm{h}$ at $37^{\circ} \mathrm{C}$. Mass spectrometry proceeded as described below.

To identify individual peptides interacting with the RNA, $10 \mu \mathrm{g}$ Pol II were added to $1 \mu \mathrm{g}$ poly $(\mathrm{U})_{50}$ RNA in $10 \mu \mathrm{L}$ modified Binding Buffer (50 mM Tris $\mathrm{pH} 8,40 \mathrm{mM} \mathrm{NaCl}, 5 \mathrm{mM} \mathrm{MgCl}$, $3 \mathrm{mM}$ DTT). Pol II binding and UV crosslinking were done as above. Samples were briefly denatured at $95^{\circ} \mathrm{C}$ and then incubated overnight at $37^{\circ} \mathrm{C}$ with $20 \mu \mathrm{g}$ sequence grade trypsin (Promega). Trypsin-digested samples were denatured at $95^{\circ} \mathrm{C}$ in formamide and separated on a $6 \%$ denaturing gel. The location of free and shifted RNA was again determined using a parallel radiolabeled sample.
The shifted signal was excised, and RNA was recovered by passive elution overnight at $37^{\circ} \mathrm{C}$ in water containing $50 \mathrm{ng}$ RNase A. Mass spectrometry proceeded as described below.

\section{LC-MS/MS analysis}

For subunit identification, the excised gel slice from Figure 7A was washed consecutively with water, 50\% acetonitrile, and $100 \mathrm{mM}$ ammonium bicarbonate buffer. The washed gel slice was dehydrated with $100 \%$ acetonitrile and dried down in a centrifugal drier with no heat. Proteins were in-gel reduced ( $5 \mathrm{mM}$ DTT for $60 \mathrm{~min}$, at room temperature), alkylated ( $10 \mathrm{mM}$ iodoacetic acid for $60 \mathrm{~min}$, at room temperature in the dark), and digested with $1 \mu \mathrm{g}$ trypsin (Promega, sequence grade) in $25 \mathrm{mM}$ ammonium bicarbonate at $37^{\circ} \mathrm{C}$ overnight. Trypsin digestion was quenched by adding trifluoroacetic acid to a final concentration of $0.4 \%$, and supernatant was collected by centrifugation. Peptides were further extracted from gel slices by incubating in $50 \%$ acetonitrile with $0.1 \%$ trifluoroacetic acid twice for $10 \mathrm{~min}$ each. Supernatants were combined, desalted using a C18 microtip column (Millipore, Ziptip), and subjected to LCMS/MS analysis. For peptide identification, the digested solubilized sample from Figure 7B was extracted as above, collected by centrifugation, and desalted with C18 microtip (Millipore, Ziptip) prior to LC-MS/MS analysis. For both sets of experiments, each replicate was repeated with a sample containing no RNA as a negative control.

Peptides reconstituted in $0.1 \%$ TFA solution were analyzed on a hybrid type LTQ-Orbitrap XL mass spectrometer (Thermo Fisher Scientific) interfaced with an RP-nanoLC (Eksigent Technologies). Peptides were separated on a C18 capillary column $(75 \mu \mathrm{m} \times 18 \mathrm{~cm}$, in-house packed with $3 \mu \mathrm{m}$ C18 resin from Sepax) over a 240 min gradient of increasing solvent B ( $90 \%$ acetonitrile with $0.1 \%$ formic acid) from $10 \%$ to $40 \%$ at a flow rate of $200 \mathrm{~nL} / \mathrm{min}$, where solvent A was $0.1 \%$ formic acid in water. Eluted peptides were introduced into the mass spectrometer via a chip-based nanoESI source (Advion, Triversa Nanomate) in positive ion mode. MS spectra were acquired in data-dependent mode by alternating single MS scan $(300-1700 \mathrm{~m} / \mathrm{z})$ in the orbitrap analyzer and sequential CID (collision induced dissociation)-MS/MS scans in the LTQ for the eight most intense ions exceeding a signal threshold of 3000 ion counts from each MS scan. MS scans were acquired with a resolution set at 60,000 at $400 \mathrm{~m} / \mathrm{z}$ and an automatic gain control (AGC) target of $5 \times 10^{5}$. To increase the duty cycle for efficient peptide identification, recurring precursor ions and ions with $1+$ or unassigned charge states were excluded from MS/MS acquisition. Two replicate LC-MS/MS analyses were performed for each sample and combined for peptide identification.

Peak lists were generated from RAW data files using MaxQuant (ver 1.0.13.13), and queried against a chimeric forward and reverse protein sequence database of yeast from Saccharomyces Genome Database by Mascot (ver. 2.4, Matrix Science). The mass accuracy for precursor ions was set at $7 \mathrm{ppm}$, and mass accuracy for fragmentation ions in MS/MS was set at $0.8 \mathrm{Da}$. Carbamidomethylation (Cys) as a fixed modification and oxidation (Met), and pyrol-Glu (Glu) as variable modifications were included. In a separate search for crosslinked peptides, mono-UMP $(+322.020217 \mathrm{Da})$ and diUMP (+628.045519 Da) on Cys, Phe, Met, Trp, His, Lys, and Tyr were specified as variable modifications by photochemical reaction. Peptides were identified at a false discovery rate of $1 \%$.

In the experiments to identify subunits (Fig. 7A), we identified peptides predominantly derived from Rpb1 and Rpb2 as dominant 
components of crosslinked Pol II-poly(U) (Table 1). Photo-crosslinked peptide conjugates containing RNA mono- and dinucleotides were not detected in the tryptic peptide mixtures. The low ionization efficiency of nucleic acids by electrospray in positive ion mode often causes signal suppression of crosslinked peptide-RNA entities (Potier et al. 1994; Sannes-Lowery et al. 1997). Also, unknown photoreaction mechanism of nucleotides, adverse reactions caused by long UV irradiation (Kubasek et al. 1993), hampers prediction of the final products. In CID fragmentation of peptide-nucleic acid crosslinks, abundant neutral loss of nucleic acid moiety has been observed resulting in lack of informative peptide fragments and thus failure in accurate identification of crosslinked peptides (Golden et al. 1999; Deterding et al. 2000).

From the database search for peptides with mono-UMP $(+322.020217 \mathrm{Da})$ and di-UMP (+628.045519 Da) modifications on side chains of Cys, Hys, Tyr, Trp, Lys, Phe, and Met, no RNA modified peptides were detected. The lack of RNA-modified peptides is likely due to a combination of low yield of the photo-crosslinking reaction, poor fragmentation efficiency of peptide-RNA conjugates, and low recovery of gel electrophoresis. Nonetheless, we did identify unmodified Pol II peptides from the digested band from Figure 7B (Table 2). No Pol II peptides were found in the control band (no UV) at the same migration distance on the gel, consistent with the identified peptides being the products of the RNase A digest of the Pol II-poly(U) band.

\section{ACKNOWLEDGMENTS}

The authors thank Ralph Davis and Roger Kornberg for the generous gift of purified yeast Pol II. The authors additionally thank Roger Kornberg for helpful discussion and critical reading of the manuscript prior to publication. This work was supported by the National Institutes of Health (T32 GM07544 predoctoral fellowship support for D.A.P., P41 RR18627 to P.C.A., R01 GM097260 to C.D.K., and R01 GM082875 to D.R.E.) and by the Welch Foundation (A-1763 to C.D.K.).

Received June 1, 2013; accepted January 22, 2014.

\section{REFERENCES}

Allen TA, Von Kaenel S, Goodrich JA, Kugel JF. 2004. The SINE-encoded mouse B2 RNA represses mRNA transcription in response to heat shock. Nat Struct Mol Biol 11: 816-821.

Batzer MA, Deininger PL. 2002. Alu repeats and human genomic diversity. Nat Rev Genet 3: 370-379.

Bernecky C, Grob P, Ebmeier CC, Nogales E, Taatjes DJ. 2011. Molecular architecture of the human Mediator-RNA polymerase II-TFIIF assembly. PLoS Biol 9: e1000603.

Bertrand E, Houser-Scott F, Kendall A, Singer RH, Engelke DR. 1998. Nucleolar localization of early tRNA processing. Genes Dev 12: 2463-2468.

Bolton EC, Boeke JD. 2003. Transcriptional interactions between yeast tRNA genes, flanking genes and Ty elements: A genomic point of view. Genome Res 13: 254-263.

Cai G, Imasaki T, Yamada K, Cardelli F, Takagi Y, Asturias FJ. 2010. Mediator head module structure and functional interactions. Nat Struct Mol Biol 17: 273-279.

Cramer P, Bushnell DA, Kornberg RD. 2001. Structural basis of transcription: RNA polymerase II at 2.8 angstrom resolution. Science 292: $1863-1876$.
D’Ambrosio C, Schmidt CK, Katou Y, Kelly G, Itoh T, Shirahige K, Uhlmann F. 2008. Identification of cis-acting sites for condensin loading onto budding yeast chromosomes. Genes Dev 22: 22152227.

Deterding LJ, Prasad R, Mullen GP, Wilson SH, Tomer KB. 2000. Mapping of the 5'-2-deoxyribose-5-phosphate lyase active site in DNA polymerase $\beta$ by mass spectrometry. J Biol Chem 275: $10463-$ 10471.

Elmlund D, Davis R, Elmlund H. 2010. Ab initio structure determination from electron microscopic images of single molecules coexisting in different functional states. Structure 18: 777-786.

Espinoza CA, Allen TA, Hieb AR, Kugel JF, Goodrich JA. 2004. B2 RNA binds directly to RNA polymerase II to repress transcript synthesis. Nat Struct Mol Biol 11: 822-829.

Garrett RA, Olesen SO. 1982. Structure of eukaryotic 5S ribonucleic acid: A study of Saccharomyces cerevisiae $5 \mathrm{~S}$ ribonucleic acid with ribonucleases. Biochemistry 21: 4823-4830.

Golden MC, Resing KA, Collins BD, Willis MC, Koch TH. 1999. Mass spectral characterization of a protein-nucleic acid photocrosslink. Protein Sci 8: 2806-2812.

Good PD, Kendall A, Ignatz-Hoover J, Miller EL, Pai DA, Rivera SR, Carrick B, Engelke DR. 2013. Silencing near tRNA genes is nucleosome-mediated and distinct from boundary element function. Gene 526: 7-15.

Goodman HM, Olson MV, Hall BD. 1977. Nucleotide sequence of a mutant eukaryotic gene: The yeast tyrosine-inserting ochre suppressor SUP4-o. Proc Natl Acad Sci 74: 5453-5457.

Haeusler RA, Pratt-Hyatt M, Good PD, Gipson TA, Engelke DR. 2008. Clustering of yeast tRNA genes is mediated by specific association of condensin with tRNA gene transcription complexes. Genes Dev 22: 2204-2214.

Häsler J, Strub K. 2006. Alu elements as regulators of gene expression. Nucleic Acids Res 34: 5491-5497.

Hawkins PG, Morris KV. 2008. RNA and transcriptional modulation of gene expression. Cell Cycle 7: 602-607.

He Y, Fang J, Taatjes DJ, Nogales E. 2013. Structural visualization of key steps in human transcription initiation. Nature 495: 481-486.

Hull MW, Erickson J, Johnston M, Engelke DR. 1994. tRNA genes as transcriptional repressor elements. Mol Cell Biol 14: 1266-1277.

Johnson TL, Chamberlin MJ. 1994. Complexes of yeast RNA polymerase II and RNA are substrates for TFIIS-induced RNA cleavage. Cell 77: 217-224.

Kaplan CD, Larsson KM, Kornberg RD. 2008. The RNA polymerase II trigger loop functions in substrate selection and is directly targeted by a-amanitin. Mol Cell 30: 547-556.

Kassavetis GA, Braun BR, Nguyen LH, Geiduschek EP. 1990. S. cerevisiae TFIIIB is the transcription initiation factor proper of RNA polymerase III, while TFIIIA and TFIIIC are assembly factors. Cell 60: 235-245.

Kettenberger H, Eisenfuhr A, Brueckner F, Theis M, Famulok M, Cramer P. 2006. Structure of an RNA polymerase II-RNA inhibitor complex elucidates transcription regulation by noncoding RNAs. Nat Struct Mol Biol 13: 44-48.

Kinsey PT, Sandmeyer SB. 1991. Adjacent pol II and pol III promoters: Transcription of the yeast retrotransposon Ty3 and a target tRNA gene. Nucleic Acids Res 19: 1317-1324.

Kubasek WL, Spann D, Hockensmith JW. 1993. Laser cross-linking of proteins to nucleic acids: Photodegradation and alternative photoproducts of the bacteriophage T4 gene 32 protein. Photochem Photobiol 58: 1-10.

Kurokawa R, Rosenfeld MG, Glass CK. 2009. Transcriptional regulation through noncoding RNAs and epigenetic modifications. RNA Biol 6: 233-236.

Lehmann E, Brueckner F, Cramer P. 2007. Molecular basis of RNA-dependent RNA polymerase II activity. Nature 450: 445-449.

Lunyak VV, Atallah M. 2011. Genomic relationship between SINE retrotransposons, Pol III-Pol II transcription, and chromatin organization: The journey from junk to jewel. Biochem Cell Biol 89: 495-504. 
Maraia RJ, Intine RV. 2002. La protein and its associated small nuclear and nucleolar precursor RNAs. Gene Expr 10: 41-57.

Mariner PD, Walters RD, Espinoza CA, Drullinger LF, Wagner SD, Kugel JF, Goodrich JA. 2008. Human Alu RNA is a modular transacting repressor of mRNA transcription during heat shock. Mol Cell 29: 499-509.

Marvin MC, Walker SC, Fierke CA, Engelke DR. 2011. Binding and cleavage of unstructured RNA by nuclear RNase P. RNA 17: 14291440.

Milligan JF, Uhlenbeck OC. 1989. Synthesis of small RNAs using T7 RNA polymerase. Methods Enzymol 180: 51-62.

Moqtaderi Z, Struhl K. 2004. Genome-wide occupancy profile of the RNA polymerase III machinery in Saccharomyces cerevisiae reveals loci with incomplete transcription complexes. Mol Cell Biol 24: 4118-4127.

Morris KV. 2011. The emerging role of RNA in the regulation of gene transcription in human cells. Semin Cell Dev Biol 22: 351-358.

Murakami K, Elmlund H, Kalisman N, Bushnell DA, Adams CM, Azubel M, Elmlund D, Levi-Kalisman Y, Liu X, Gibbons BJ, et al. 2013. Architecture of an RNA polymerase II transcription pre-initiation complex. Science 342: 1238724.

Okada N. 1991. SINEs. Curr Opin Genet Dev 1: 498-504.

Perrod S, Gasser SM. 2003. Long-range silencing and position effects at telomeres and centromeres: Parallels and differences. Cell Mol Life Sci 60: 2303-2318.

Phizicky EM, Hopper AK. 2010. tRNA biology charges to the front. Genes Dev 24: 1832-1860.

Ponicsan SL, Houel S, Old WM, Ahn NG, Goodrich JA, Kugel JF. 2013. The non-coding B2 RNA binds to the DNA cleft and active-site region of RNA polymerase II. J Mol Biol 425: 3625-3638.

Potier N, Van Dorsselaer A, Cordier Y, Roch O, Bischoff R. 1994. Negative electrospray ionization mass spectrometry of synthetic and chemically modified oligonucleotides. Nucleic Acids Res 22: 3895-3903.

Pratt-Hyatt M, Pai DA, Haeusler RA, Wozniak GG, Good PD, Miller EL, McLeod IX, Yates JR III, Hopper AK, Engelke DR. 2013. Mod5 protein binds to tRNA gene complexes and affects local transcriptional silencing. Proc Natl Acad Sci 110: E3081-E3089.

Price AL, Eskin E, Pevzner PA. 2004. Whole-genome analysis of Alu repeat elements reveals complex evolutionary history. Genome Res 14: $2245-2252$.
Roberts DN, Stewart AJ, Huff JT, Cairns BR. 2003. The RNA polymerase III transcriptome revealed by genome-wide localization and activity-occupancy relationships. Proc Natl Acad Sci 100: 14695-14700.

Rusche LN, Kirchmaier AL, Rine J. 2003. The establishment, inheritance, and function of silenced chromatin in Saccharomyces cerevisiae. Annu Rev Biochem 72: 481-516.

Sannes-Lowery KA, Mack DP, Peifeng H, Mei HY, Loo JA. 1997. Positive ion electrospray ionization mass spectrometry of oligonucleotides. J Am Soc Mass Spectrom 8: 90-95.

Sawadogo M. 1981. On the inhibition of yeast RNA polymerases A and B by tRNA and a-amanitin. Biochem Biophys Res Commun 98: 261-267.

Soutourina J, Wydau S, Ambroise Y, Boschiero C, Werner M. 2011. Direct interaction of RNA polymerase II and mediator required for transcription in vivo. Science 331: 1451-1454.

Storz G, Altuvia S, Wassarman KM. 2005. An abundance of RNA regulators. Annu Rev Biochem 74: 199-217.

Thomas M, Chedin S, Carles C, Riva M, Famulok M, Sentenac A. 1997. Selective targeting and inhibition of yeast RNA polymerase II by RNA aptamers. J Biol Chem 272: 27980-27986.

Thompson M, Haeusler RA, Good PD, Engelke DR. 2003. Nucleolar clustering of dispersed tRNA genes. Science 302: 1399-1401.

Wang L, Haeusler RA, Good PD, Thompson M, Nagar S, Engelke DR. 2005. Silencing near tRNA genes requires nucleolar localization. J Biol Chem 280: 8637-8639.

Wassarman KM, Saecker RM. 2006. Synthesis-mediated release of a small RNA inhibitor of RNA polymerase. Science 314: 16011603.

Weiner AM. 2002. SINEs and LINEs: The art of biting the hand that feeds you. Curr Opin Cell Biol 14: 343-350.

Westover KD, Bushnell DA, Kornberg RD. 2004. Structural basis of transcription: Separation of RNA from DNA by RNA polymerase II. Science 303: 1014-1016.

Wilusz CJ, Wilusz J. 2005. Eukaryotic Lsm proteins: Lessons from bacteria. Nat Struct Mol Biol 12: 1031-1036.

Yakovchuk P, Goodrich JA, Kugel JF. 2009. B2 RNA and Alu RNA repress transcription by disrupting contacts between RNA polymerase II and promoter DNA within assembled complexes. Proc Natl Acad Sci 106: 5569-5574. 

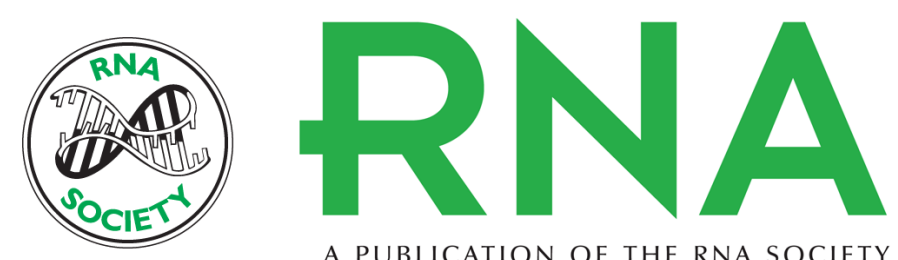

A PUBLICATION OF THE RNA SOCIETY

\section{RNAs nonspecifically inhibit RNA polymerase II by preventing binding to the DNA template}

Dave A. Pai, Craig D. Kaplan, Hye Kyong Kweon, et al.

RNA 2014 20: 644-655 originally published online March 10, 2014

Access the most recent version at doi:10.1261/rna.040444.113

References This article cites 57 articles, 22 of which can be accessed free at: http://rnajournal.cshlp.org/content/20/5/644.full.html\#ref-list-1

Creative This article is distributed exclusively by the RNA Society for the first 12 months after the Commons full-issue publication date (see http://rnajournal.cshlp.org/site/misc/terms.xhtml). After 12 License months, it is available under a Creative Commons License (Attribution-NonCommercial 4.0 International), as described at http://creativecommons.org/licenses/by-nc/4.0/.

Email Alerting Receive free email alerts when new articles cite this article - sign up in the box at the Service top right corner of the article or click here. 